\title{
HUBUNGAN ANTARA PRESTASI BELAJAR PENDIDIKAN SISTEM GANDA DENGAN MOTIVASI SISWA MEMASUKI DUNIA KERJA BIDANG TEKNIK KONSTRUKSI BATU DAN BETON (STUDI DESKRIPTIF ANALITIS PADA SISWA SMK NEGERI 4 JAKARTA PROGRAM KEAHLIAN TEKNIK KONSTRUKSI BATU DAN BETON TAHUN PELAJARAN 2011/2012)
}

\author{
Tri Puspita Sari, Daryati, Dadang Suyadi SS
}

\begin{abstract}
This research aims to get the relationship between learning achievement of Double System Education and student's motivation to involve in the field of masonry and concrete construction working environment. The duration of research is conducted in May 24th $-25^{\text {th }} 2012$.

SMK Negeri 4 Jakarta is chosen to be the place of conducting this research. The population of this research is the students of the second and third grade majoring in masonry and concrete construction who have performed Double System Education activity. The sample of this research is the second grade students of SMK Negeri 4 Jakarta majoring in masonry and concrete construction who have performed Double System Education activity. The research method is surveying using correlation approach. The questionnaire consists of 62 items of statement and it is tested to 10 students in the third grade of SMK Negeri 4 Jakarta majoring in masonry and concrete construction. After the test, there is a valid instrument for data collecting in the sample and number of valid items. Finally, there are 41 valid items.

Either learning achievement variable of Double System Education or student's motivation to involve in the working environment has shown normal distribution. Coefficient of correlation $\left(r_{x y}\right)$ equals 0.85 . Regression equation between learning achievement of Double System Education and student's motivation to involve in the working environment is $\hat{Y}=17.09+1.67 X$. The hypothesis results from the table $t_{\text {table }}$ and calculation thitung are 2.09 and 7.22 respectively, $H_{0}$ is rejected and $H_{a}$ is accepted. The result shows that there is a positive and significant relationship between learning achievement variable of Double System Education or student's motivation to involve in the field of masonry and concrete working environment
\end{abstract}

Keywords: learning achievement, student's motivation

\begin{tabular}{|l|r|r|}
\hline Tri Puspita Sari & Dra. Daryati, MT \\
Alumni Jurusan Teknik Sipil & Jurusan Teknik Sipil \\
Fakultas Teknik & Fakultas Teknik & Drs. Dadang Suyadi SS,MS \\
Universitas Negeri Jakarta, 13220 & $\begin{array}{r}\text { Jniversitas Negeri Jakarta, 13220 Teknik Sipil } \\
\text { email : daryati_sr@ymail.com }\end{array}$ & $\begin{array}{r}\text { Fakultas Teknik } \\
\text { Universitas Negeri Jakarta, 13220 }\end{array}$ \\
\hline
\end{tabular}




\section{PENDAHULUAN}

Di era globalisasi tuntutan untuk memenuhi lapangan dunia kerja bukanlah hal yang mudah. Semua dituntut untuk lebih pintar, kreatif, inovatif, mempunyai keahlian di bidangnya, peka terhadap keadaan sekitar, dan bisa menentukan pekerjaan, sesuai keahlian dan kemampuan. Hal tersebut bisa didapatkan melalui PSG (Pendidikan Sistem Ganda) yang ada di sekolah. PSG merupakan bentuk penyelenggaraan pendidikan dan pelatihan keahlian kejuruan yang secara sistematik dan sinkron menyatukan antara program pendidikan di sekolah dengan program penguasaan keahlian yang diperoleh melalui kegiatan bekerja langsung di dunia kerja, terarah untuk mencapai suatu tingkat keahlian profesional.

Berdasarkan data alumni tamatan SMK Negeri 4 Jakarta Tahun Pelajaran 2010/ 2011 yang telah bekerja sesuai dengan program keahlian Teknik Konstruksi Batu dan Beton adalah $57,7 \%$. Alumni selain bekerja pada bidang Teknik Konstruksi Batu dan Beton di dalam negeri ada juga alumni yang bekerja di luar negeri seperti negara Malaysia. Sedangkan 42,3\% bekerja tidak sesuai dengan program keahlian Teknik Konstruksi Batu dan Beton.

Dalam kehidupan sehari-hari kita sering melihat, mendengar atau merasakan terbentuk dan berkembangnya motivasi sebagai akibat adanya kebutuhan. Motivasi seseorang sangat dipengaruhi oleh intensitas kebutuhan orang tersebut terhadap apa yang diinginkannya. Motivasi seseorang pada dunia kerja sangat bergantung dari apa yang mereka pelajari atau sesuatu yang mereka sukai. Setiap siswa memiliki keinginan untuk mencapai cita-cita yang mereka inginkan berdasarkan motivasi mereka pada dunia kerja yang dapat mereka jalani sesuai dengan keahlian yang didapatkan pada saat sekolah.

Siswa program keahlian Teknik Konstruksi Batu Beton dan pada dasarnya diarahkan untuk langsung terjun ke dunia kerja. Hal tersebut dapat terlihat dengan sistem pembelajaran di SMK Negeri 4 yang lebih mendorong siswa pada segi penguasaan praktik kerja, seperti praktik di sekolah dan PSG di dunia kerja. Terdapat beberapa faktor yang mempengaruhi motivasi siswa terhadap dunia kerja yaitu faktor intern atau yang berasal dari dalam diri dan faktor ekstern yang berasal dari luar atau lingkungan sekitar. Faktor dari dalam yaitu banyaknya siswa yang percaya diri karena mempunyai bakat atau kemampuan dalam bidang keahlian yang dimilikinya. Sedangkan faktor dari luar yaitu dukungan dari lingkungan sekitar seperti teman, keluarga, dan kerabat serta tempat kerja itu sendiri, sehingga siswa termotivasi untuk memasuki dunia kerja. Kegunaan penelitian adalah membentuk SDM yang berbudi luhur dan memiliki keahlian yang profesional. Membangun sikap kerja dan kepribadian yang utuh sebagai pekerja. Peserta didik akan lebih percaya diri karena orang lain dapat memahami apa yang dipahaminya dan pengetahuannya diterima oleh masyarakat.

\section{Prestasi Belajar, Siswa, dan Penilaian Prestasi Belajar PSG di SMK 4}

Menurut Marsun dan Martaniah dalam Sia Tjundjing (dalam Wahyuningsih, 2000), bahwa prestasi belajar merupakan hasil kegiatan belajar, yaitu sejauh mana peserta didik menguasai bahan pelajaran yang

Hubungan antara Prestasi Belajar Pendidikan Sistem Ganda dengan Motivasi Siswa Memasuki Dunia Kerja Bidang Teknik Konstruksi Batu dan Beton (Studi Deskriptif Analitis pada Siswa SMK Negeri 4 Jakarta Program Keahlian Teknik 
diajarkan, yang diikuti oleh munculnya perasaan puas bahwa ia telah melakukan sesuatu dengan baik. Prestasi belajar di bidang pendidikan adalah hasil dari pengukuran terhadap peserta didik yang meliputi faktor kognitif, afektif, dan psikomotor setelah mengikuti proses pembelajaran yang diukur dengan menggunakan instrumen tes atau instrumen yang relevan. Untuk meraih prestasi belajar yang baik, banyak sekali faktor yang perlu diperhatikan, karena di dalam dunia pendidikan tidak sedikit siswa yang mengalami kegagalan.

Siswa atau anak didik adalah salah satu komponen manusiawi yang menempati posisi sentral dalam proses belajar mengajar. Di dalam proses belajar mengajar, siswa sebagai pihak yang ingin meraih cita-cita, memiliki tujuan dan kemudian ingin mencapainya secara optimal.

Penilaian prestasi belajar PSG di SMK 4 Jakarta Program Keahlian Teknik Konstruksi Batu dan Beton diberikan oleh instruktur di industri/ perusahaan dan diberikan juga oleh pihak sekolah dari Program Keahlian Teknik Konstruksi Batu Beton. Pihak industri mempunyai beberapa unsur penilaian untuk daftar penilaian siswa yang telah mengikuti PSG. Unsur penilaian tersebut terdiri dari disiplin, kerja sama, inisiatif, kerajinan, prestasi kerja, rasa tanggung jawab, kemampuan, kemauan, kehadiran. Dari kesembilan unsur penilaian tersebut dinilai berdasarkan dari hasil pengamatan instruktur industri/ tes yang diberikan oleh instruktur industri/ hasil yang dicapai pada bulan yang berjalan. Penilaian terdiri dari dua angka yaitu dengan nilai angka dan nilai huruf. Keterangan dari nilai dengan angka dan nilai dengan huruf adalah sebagai berikut:

Tabel 1. Keterangan dengan Nilai Angka dan Huruf

\begin{tabular}{|c|c|c|c|}
\hline \multicolumn{2}{|c|}{ Keterangan dengan Nilai Angka } & \multicolumn{2}{c|}{ Keterangan dengan Nilai Huruf } \\
\hline $91-100$ & Baik sekali & A & Baik sekali \\
\hline $76-90$ & Baik & B & Baik \\
\hline $60-75$ & Cukup & C & Cukup \\
\hline $41-59$ & Kurang & D & Kurang \\
\hline $10-40$ & Kurang sekali & E & Kurang sekali \\
\hline
\end{tabular}

Sumber : Jurnal PSG SMK Negeri 4 Jakarta

Dalam penelitian ini pengukuran prestasi belajar menggunakan penilaian sebagai pengukur keberhasilan (fungsi formatif), yaitu menilai laporan (jurnal) setelah siswa melakukan kegiatan PSG.

\section{Pendidikan Sistem Ganda}

Pakpahan (dalam Made Wena, 1994) menyatakan sistem ganda adalah suatu bentuk penyelenggaraan pendidikan keahlian kejuruan yang memadukan secara sistematik dan sinkron program pendidikan di sekolah dan program penguasaan keahlian yang diperoleh melalui kegiatan bekerja langsung pada bidang pekerjaan yang relevan/ terarah untuk mencapai penguasaan kemampuan keahlian tertentu.

Di SMK Negeri 4 Jakarta pelaksanaan program Pendidikan Sistem Ganda (PSG) menggunakan model block release. Dengan model ini siswa dapat berkonsentrasi penuh terhadap pekerjaan yang terdapat di industri yang ditempati. Siswa yang melaksanakan PSG tetap dipantau dari pihak sekolah. 
Kegiatan PSG di SMK Negeri 4 Jakarta bukan mata pelajaran melainkan untuk mengaplikasikan pada standar kompetensi dan kompetensi dasar Program Keahlian Teknik Konstruksi Batu dan Beton serta menambah wawasan di lapangan. Kegiatan program PSG dilaksanakan selama kurang lebih 3 bulan yang dilaksanakan oleh siswa tingkat 2 atau siswa kelas 2. Pelaksanaannya sesuai dengan ketentuanketentuan yang tertuang dalam Undang-undang Nomor 2 tahun 1989 tentang Sistem Pendidikan Nasional, PP Nomor 20 tahun 1990 tentang Pendidikan Menengah, PP Nomor 39 tahun 1992 tentang Peran serta Masyarakat dalam Pendidikan Nasional, Kepmendikbud Nomor 080/U/1992 tentang Sekolah Menengah Kejuruan dan Kepmendikbud Nomor 080/U/1993 tentang Kurikulum SMK. Tempat pelaksanaan PSG SMK Negeri 4 adalah perusahaan/industri yang telah bekerja sama dengan SMK Negeri 4 Jakarta.

\section{Motivasi di Dunia Kerja}

Motivasi merupakan pendorong bagi perbuatan seseorang. la menyangkut soal mengapa berbuat demikian dan apa tujuannya sehingga seseorang berbuat demikian. Untuk mencari jawaban dari pernyataan tersebut, mungkin kita harus mencari apa yang mendorongnya dari dalam dan apa pendorongnya atau faktor dari luar dan stimulus menariknya untuk melakukan perbuatan itu. Mungkin seseorang terdorong oleh nalurinya, atau oleh keinginannya memperoleh kekuasaan, atau mungkin juga karena kebutuhan hidupnya yang sangat mendesak.

Keberhasilan usaha seseorang di dunia kerja sangat ditentukan oleh faktor-faktor yang berasal dari dalam maupun dari luar yang mengakibatkan seseorang termotivasi untuk memasuki dunia kerja. Motivasi merupakan suatu respon yang positif yang berhubungan secara terus menerus, terhadap faktor yang memberikan kepuasan. Dengan timbulnya motivasi ini akan mengakibatkan seseorang untuk lebih giat dalam mencapai tujuannya.

Dengan tercapainya sebuah tujuan ini merupakan suatu bentuk dari prestasi belajar. Prestasi belajar adalah hasil yang telah dicapai dari adanya perubahan tingkah laku pada diri seseorang berupa pengetahuan, sikap dan keterampilan. Dalam suatu Pendidikan Sistem Ganda, prestasi belajar seorang siswa diberikan dalam bentuk nilai. Nilai yang diberikan kepada siswa oleh instruktur/ pembimbing lapangan dengan penilaian yang meliputi : disiplin, kerja sama, inisiatif, kerajinan, prestasi kerja, rasa tanggung jawab, kemampuan, kemauan, kehadiran. Dengan adanya penilaian yang meliputi kesembilan aspek di atas diharapkan tujuan dilaksanakannya kegiatan PSG itu tercapai. Selain untuk mendapatkan keterampilan dalam bekerja juga untuk memberikan motivasi kepada siswa untuk memasuki dunia kerja pada bidang konstruksi batu dan beton.

Mendapatkan nilai terbaik dalam kegiatan PSG merupakan kebanggaan tersendiri bagi siswa, dengan didapatnya nilai yang tinggi tersebut diharapkan motivasi mereka untuk memasuki dunia kerja pada bidang konstruksi batu dan beton juga semakin tinggi.

Hubungan antara Prestasi Belajar Pendidikan Sistem Ganda dengan Motivasi Siswa Memasuki Dunia Kerja Bidang Teknik Konstruksi Batu dan Beton (Studi Deskriptif Analitis pada Siswa SMK Negeri 4 Jakarta Program Keahlian Teknik 


\section{METODE}

Tujuan penelitian ini adalah untuk mengetahui ada tidaknya hubungan yang positif dan signifikan antara prestasi belajar PSG (Pendidikan Sistem Ganda) dengan motivasi siswa memasuki dunia kerja Bidang Teknik Konstruksi Batu dan Beton pada Program Keahlian Teknik Konstruksi Batu dan Beton SMK Negeri 4 Jakarta. Penelitian ini dilakukan di SMK Negeri 4 Jakarta, yang berlokasi di Jalan Rorotan VI No. 1 Cilincing, Jakarta Utara 14140. Waktu penelitian dilaksanakan pada bulan Mei 2012 pada Semester Genap Tahun Pelajaran 2011/ 2012.

Metode penelitian yang digunakan dalam penelitian ini adalah metode survei dengan pendekatan korelasional. Penelitian survei dimaksudkan untuk mengetahui pendapat masyarakat (Arikunto, 2007). Populasi dalam penelitian ini adalah siswa kelas 2 dan kelas 3 Teknik Konstruksi Batu dan Beton SMK 4 Jakarta Tahun Pelajaran 2011/ 2012, yang telah selesai melaksanakan kegiatan PSG (Pendidikan Sistem Ganda) sebanyak 49 orang. Teknik pengambilan sampel pada penelitian ini adalah sampling jenuh. Jumlah sampel yaitu sebanyak 22 orang kelas 2 Teknik Konstruksi Batu dan Beton SMK 4 Jakarta Tahun Pelajaran 2011/ 2012 yang telah selesai melaksanakan kegiatan PSG.

Variabel bebas dalam penelitian ini adalah prestasi belajar PSG, sedangkan variabel terikatnya adalah motivasi siswa memasuki dunia kerja. Dalam penelitian ini, teknik pengumpulan yaitu variabel prestasi belajar PSG menggunakan nilai nilai hasil PSG siswa kelas 2 Teknik Konstruksi Batu dan Beton SMK Negeri 4 Jakarta Tahun Pelajaran 2011/ 2012. Sedangkan variabel motivasi siswa memasuki dunia kerja menggunakan teknik penyebaran angket/ kuesioner. Bentuk angket/kuesioner yang disusun menggunakan Skala Likert. Terdapat lima alternatif jawaban untuk setiap pertanyaan atau pernyataan dalam angket penelitian ini. Lima alternatif jawaban adalah sebagai berikut :

Tabel 2. Skala Likert untuk Angket Variabel $X$ dan $Y$

\begin{tabular}{|c|c|c|c|c|c|}
\hline \multirow{3}{*}{ Pernyataan } & \multicolumn{6}{|c|}{ Bobot Skor } \\
\cline { 2 - 6 } & $\begin{array}{c}\text { Sangat Setuju } \\
\text { (SS) }\end{array}$ & $\begin{array}{c}\text { Setuju } \\
\text { (S) }\end{array}$ & $\begin{array}{c}\text { Netral } \\
\text { (N) }\end{array}$ & $\begin{array}{c}\text { Tidak Setuju } \\
\text { (TS) }\end{array}$ & $\begin{array}{c}\text { Sangat Tidak Setuju } \\
\text { (STS) }\end{array}$ \\
\hline Positif & 5 & 4 & 3 & 2 & 1 \\
\hline Negatif & 1 & 2 & 3 & 4 & 5 \\
\hline
\end{tabular}

Kisi-kisi instrumen motivasi siswa memasuki dunia kerja pada penelitian ini terdiri dari indikator, sub indikator, nomor item kuesioner, dan jumlah butiran dalam penelitian ini ditunjukkan pada Tabel 3 berikut.

Setelah menyusun kisi-kisi instrumen dan butir soal, dilakukan uji coba. Jumlah butir soal yang digunakan dalam uji coba yaitu 62 item pernyataan berupa pernyataan dengan lima jawaban alternatif yaitu : setuju, tidak setuju, netral, tidak setuju, dan sangat tidak setuju. Setelah dilakukan uji coba didapat 41 item pernyataan valid dan 21 item pernyataan yang tidak valid. Untuk pengambilan data digunakan 
Tabel 3. Kisi-kisi Instrumen Motivasi Siswa Memasuki Dunia Kerja Bidang Teknik Konstruksi Batu dan Beton

\begin{tabular}{|c|c|c|c|}
\hline Indikator & Sub Indikator & $\begin{array}{l}\text { No. Item } \\
\text { Kuesioner }\end{array}$ & $\begin{array}{l}\text { Jumlah } \\
\text { Butiran }\end{array}$ \\
\hline \multirow{3}{*}{ Disiplin } & - Tepat waktu & $1,8,21,36,39$ & 5 \\
\hline & - Mengikuti peraturan perusahaan & $2,18,54$ & 3 \\
\hline & - Menjalankan K3 & $3,7,14,25,27$ & 5 \\
\hline \multirow{3}{*}{ Kerja Sama } & - Komunikasi sesama teman satu tim & 4,16 & 2 \\
\hline & $\begin{array}{l}\text { - Menjalankan pekerjaan dengan bekerja } \\
\text { sama }\end{array}$ & $5,12,58$ & 3 \\
\hline & - Diskusi sesama teman satu tim & 44,53 & 4 \\
\hline \multirow[b]{2}{*}{ Inisiatif } & - Memanfaatkan sumber belajar & $6,19,23$ & 3 \\
\hline & - Belajar mandiri di lapangan/ industri & $20,42,48$ & 3 \\
\hline Kerajinan & - Kreatif bekerja & 22,47 & 2 \\
\hline \multirow{3}{*}{ Prestasi Kerja } & - Menciptakan hal-hal baru di industri & 15 & 1 \\
\hline & - Tingkat kesuksesan siswa di industri & 34 & 1 \\
\hline & - Tingkat kecerdasan siswa & 43,52 & 2 \\
\hline \multirow{3}{*}{$\begin{array}{l}\text { Rasa } \\
\text { tanggung } \\
\text { jawab }\end{array}$} & - Kesiapan dalam bekerja & $17,24,29,32,38$ & 5 \\
\hline & - Daya tahan bekerja & 9,37 & 2 \\
\hline & - Alokasi waktu & 13,28 & 2 \\
\hline \multirow[b]{2}{*}{ Kemampuan } & - Sigap dalam bekerja & $10,31,35,40$ & 4 \\
\hline & $\begin{array}{l}\text { - Mampu melakukan pendekatan dengan } \\
\text { instruktur dan pekerja lainnya di } \\
\text { lapangan }\end{array}$ & $41,45,59$ & 4 \\
\hline Kemauan & - Minat bekerja & 33,55 & 2 \\
\hline Kehadiran & - Absensi & 11 & 1 \\
\hline \multirow[t]{2}{*}{ Percaya Diri } & $\begin{array}{l}\text { - Mengukur kemampuan dari hasil belajar } \\
\text { praktik di sekolah }\end{array}$ & $46,49,56$ & 3 \\
\hline & - Mengukur kemampuan dari hasil PSG & $26,30,60$ & 3 \\
\hline \multirow{2}{*}{ Harapan } & - Mendapatkan pekerjaan & 50,57 & 2 \\
\hline & - Memperoleh insentif & $51,61,62$ & 3 \\
\hline
\end{tabular}

butir soal yang valid yaitu sebanyak 41 item pernyataan. Tujuan uji coba yaitu untuk memperoleh instrumen yang dapat digunakan untuk penelitian. Untuk uji reliabilitas, berdasarkan hasil perhitungan manual (Rumus Alpha) dan menggunakan Program SPSS versi 16 diperoleh nilai reliabilitas sebesar 0,935. Dengan nilai sebesar 0,935 mengindikasikan bahwa reliabilitas tersebut tergolong sangat kuat, artinya ketika kuesioner tersebut diujicobakan dalam waktu yang berbeda, maka akan menunjukkan hasil yang relatif sama. Teknik analisis data menggunakan uji $\mathrm{t}$, sebelum menggunakan uji $\mathrm{t}$ dilakukan uji persyaratan analisis yaitu dengan menggunakan uji normalitas, uji linieritas, dan uji korelasi Product Momen. Hipotesis statistik, yaitu $\mathrm{H}_{0}: \rho_{x y}=0, \mathrm{H}_{\mathrm{a}}: \rho_{x y}>0$.

\section{HASIL DAN PEMBAHASAN}

Sebelum dilakukan pengujian hipotesis, peneliti perlu mendeskripsikan keadaan data dari setiap variabel ukur. Deskripsi data berisi serangkaian data yang berhasil dikumpulkan, baik data pendukung seperti latar belakang lembaga/ instansi yang diteliti, struktur organisasi dan sebagainya, serta data utama yang 
diperlukan untuk pengujian hipotesis. Yang dimaksud dengan mendeskripsikan data adalah menggambarkan data yang berguna untuk memperoleh bentuk nyata dari responden, sehingga lebih mudah dimengerti peneliti atau orang lain yang tertarik dengan hasil penelitian ini. Fungsi deskripsi data adalah untuk mengadministrasi dan menampilkan ringkasan yang ada sehingga memudahkan pembaca lain mengerti substansi dan makna dari tampilan data tersebut. Data-data tersebut harus dideskripsikan secara sistematis.

Untuk mengukur variabel prestasi belajar PSG digunakan nilai akhir PSG dimana nilai terendah adalah 78 , nilai tertinggi adalah 93 , rata-rata nilai 88,64 , nilai median 90 , nilai modus 88,97 , dan nilai simpangan baku 4,47 .

Tabel 4. Distribusi Frekuensi Absolut dan Relatif Prestasi Belajar PSG

\begin{tabular}{|c|c|c|c|c|c|}
\hline \multicolumn{2}{|c|}{ Daftar Distribusi Frekuensi Absolut } & \multicolumn{3}{|c|}{ Daftar Distribusi Frekuensi Relatif } \\
\hline $\begin{array}{c}\text { Rentang Nilai } \\
\text { PSG }\end{array}$ & $\mathrm{f}_{\mathrm{i}}$ & $\mathrm{x}_{\mathrm{i}}$ & $\begin{array}{c}\text { Rentang Nilai } \\
\text { PSG }\end{array}$ & $\mathrm{f}_{\mathrm{i}}$ & $\mathrm{f}_{\mathrm{r}}(\%)$ \\
\hline $78-82$ & 3 & 80 & $78-82$ & 3 & 13,63 \\
\hline $83-87$ & 3 & 85 & $83-87$ & 3 & 13,63 \\
\hline $88-92$ & 14 & 90 & $88-92$ & 14 & 63,63 \\
\hline $93-97$ & 2 & 95 & $93-97$ & 2 & 9,10 \\
\hline
\end{tabular}

Keterangan : $\quad \mathrm{fi}=$ frekuensi

$$
\begin{aligned}
& \mathrm{xi}=\text { tanda kelas }=\left(\frac{b a+b b}{2}\right) \\
& \mathrm{fr}=\text { frekuensi relative }=\left(\frac{f_{i}}{\Sigma f_{i}} \times 100 \%\right)
\end{aligned}
$$

Berdasarkan tabel di atas dari 22 siswa, 2 siswa berada di atas nilai rata-rata, 14 siswa berada di antara rata-rata, dan 6 siswa berada di bawah rata-rata.

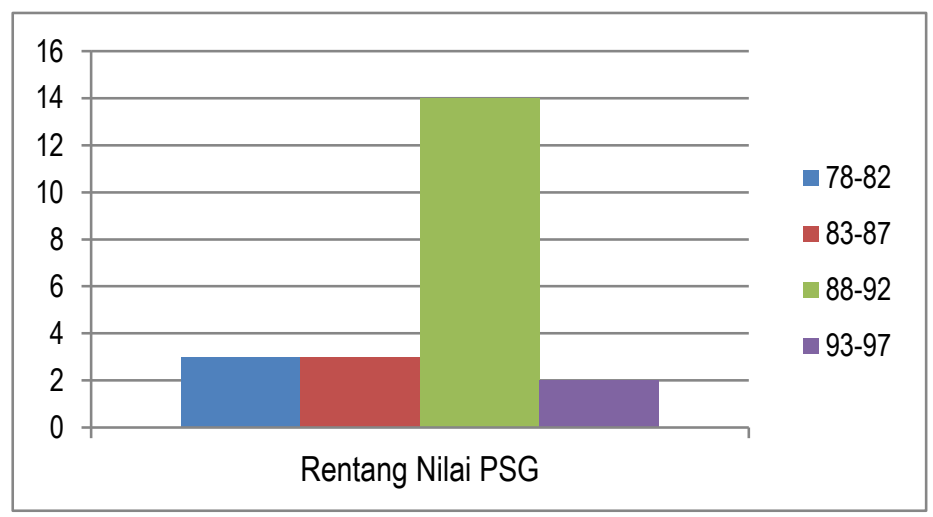

Gambar 1. Histogram Prestasi Belajar PSG

Untuk mengukur variabel motivasi siswa memasuki dunia kerja bidang teknik konstruksi batu dan beton digunakan instrumen yang terdiri dari 41 butir dalam bentuk skala Likert dimana nilai terendah 
adalah 152 , nilai tertinggi adalah 190 , rata-rata nilai 165,41 , nilai median 164,50 , nilai modus 164,84 , dan nilai simpangan baku 8,83.

Berdasarkan Tabel 5 berikut dapat dilihat dari 22 siswa, 6 siswa berada di atas nilai rata-rata, 11 siswa berada di antara rata-rata, dan 5 siswa berada di bawah rata-rata.

Tabel 5. Distribusi Frekuensi Absolut dan Relatif Motivasi Siswa Memasuki Dunia Kerja Bidang Teknik Konstruksi Batu dan Beton

\begin{tabular}{|c|c|c|c|c|c|}
\hline \multicolumn{2}{|l|}{ Daftar Distribusi Frekuensi Absolut } & \multicolumn{3}{c|}{ Daftar Distribusi Frekuensi Relatif } \\
\hline Rentang & $\mathrm{f}_{\mathrm{i}}$ & $\mathrm{x}_{\mathrm{i}}$ & Rentang & $\mathrm{f}_{\mathrm{i}}$ & $\mathrm{f}_{\mathrm{r}}(\%)$ \\
\hline $152-160$ & 5 & 156 & $152-160$ & 5 & 22,73 \\
\hline $161-169$ & 11 & 165 & $161-169$ & 11 & 50 \\
\hline $170-178$ & 5 & 174 & $170-178$ & 5 & 22,73 \\
\hline $179-187$ & 0 & 183 & $179-187$ & 0 & 0 \\
\hline $188-196$ & 1 & 192 & $188-196$ & 1 & 4,54 \\
\hline
\end{tabular}

Keterangan : $\quad \mathrm{fi}=$ frekuensi

$$
\begin{aligned}
& \mathrm{xi}=\text { tanda kelas }=\left(\frac{b a+b b}{2}\right) \\
& \mathrm{fr}=\text { frekuensi relative }=\left(\frac{f_{i}}{\sum f_{i}} \times 100 \%\right)
\end{aligned}
$$

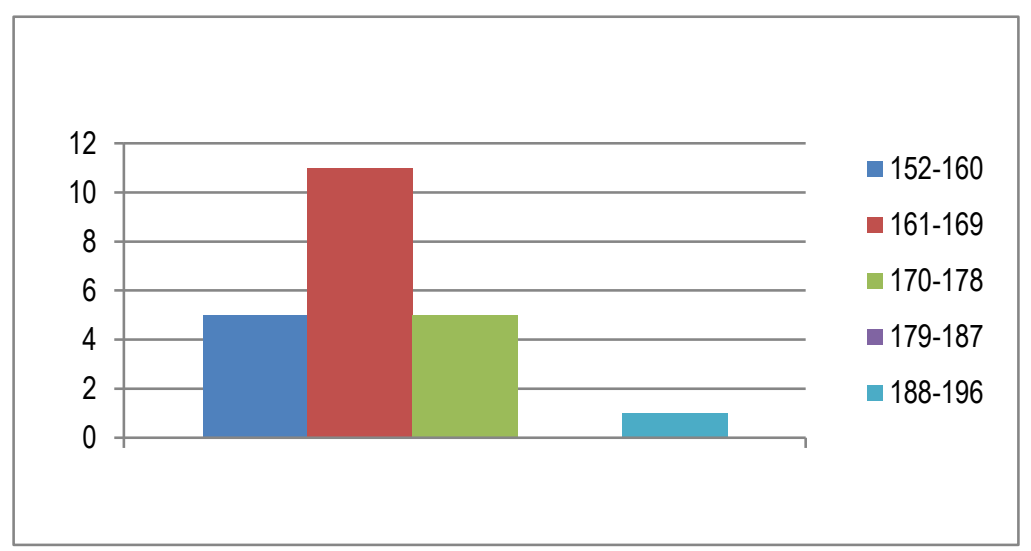

Gambar 2. Histogram Motivasi Siswa Memasuki Dunia Kerja

Pengujian normalitas menggunakan Uji Lilliefors terhadap nilai akhir PSG, menghasilkan Lhitung sebesar 0,1635 dan pada taraf kesalahan (alpha) sebesar $5 \%$ diperoleh $L_{\text {tabel }}$ sebesar 0,1888 . Ternyata $L_{\text {hitung }}<L_{\text {tabel }}$ atau $0,1635<0,1888$. Dengan demikian dapat disimpulkan bahwa sampel untuk variabel prestasi belajar PSG berasal dari populasi yang berdistribusi normal. Pengujian normalitas menggunakan Program SPSS terhadap variabel prestasi belajar PSG menghasilkan taraf signifikansi hitung (sig) sebesar 0,10 dan pada taraf kesalahan (alpha) sebesar $5 \%$ atau 0,050. Ternyata sig > alpha atau 0,10>

Hubungan antara Prestasi Belajar Pendidikan Sistem Ganda dengan Motivasi Siswa Memasuki Dunia Kerja Bidang Teknik Konstruksi Batu dan Beton (Studi Deskriptif Analitis pada Siswa SMK Negeri 4 Jakarta Program Keahlian Teknik 
0,050. Dengan demikian dapat disimpulkan bahwa sampel untuk variabel prestasi belajar PSG berasal dari populasi yang berdistribusi normal.

Pengujian normalitas menggunakan Uji Lilliefors terhadap variabel motivasi siswa memasuki dunia kerja menghasilkan $L_{\text {hitung }}$ sebesar 0,1615 dan pada taraf kesalahan (alpha) sebesar 5\% diperoleh $L_{\text {tabel }}$ sebesar 0,1888 . Ternyata $L_{\text {hitung }}<L_{\text {tabel }}$ atau $0,1615<0,1888$. Dengan demikian dapat disimpulkan bahwa sampel untuk variabel motivasi siswa memasuki dunia kerja berasal dari populasi yang berdistribusi normal. Pengujian normalitas menggunakan Program SPSS terhadap variabel motivasi siswa memasuki dunia kerja menghasilkan taraf signifikansi hitung (sig) sebesar 0,122 dan pada taraf kesalahan (alpha) sebesar 5\% atau 0,05. Ternyata sig $>$ alpha atau 0,122 >0,05. Dengan demikian dapat disimpulkan bahwa sampel untuk variabel motivasi siswa memasuki dunia kerja berasal dari populasi yang berdistribusi normal. Dengan demikian, baik variabel prestasi belajar PSG maupun variabel motivasi siswa memasuki dunia kerja telah menunjukkan berdistribusi normal, maka pengujian hipotesis menggunakan analisis regresi dan korelasi dapat dilakukan.

Uji linieritas adalah analisis yang digunakan untuk melakukan prediksi, bagaimana perubahan nilai variabel terikat bila nilai variabel bebas dinaikkan atau diturunkan nilainya (dimanipulasi). Uji regresi yang digunakan dalam penelitian ini adalah uji linieritas regresi sederhana. Uji linieritas regresi menggunakan perhitungan manual dan program SPSS versi 16. Berdasarkan perhitungan manual dan Program SPSS versi 16 hasil analisis regresi linier sederhana antara variabel prestasi belajar PSG dengan variabel motivasi siswa memasuki dunia kerja diperoleh nilai konstanta (a) sebesar 17,09 dan koefisien arah regresi $(b)$ sebesar 1,67. Dengan demikian persamaan regresi antara prestasi belajar PSG dengan motivasi siswa memasuki dunia kerja adalah $\hat{Y}=17,09+1,67 X$. Dengan demikian dapat disimpulkan jika prestasi belajar PSG $(X)$ naik satu satuan maka akan diikuti dengan peningkatan motivasi siswa memasuki dunia kerja $(Y)$ sebesar 1,67 satuan pada konstanta 17,09.

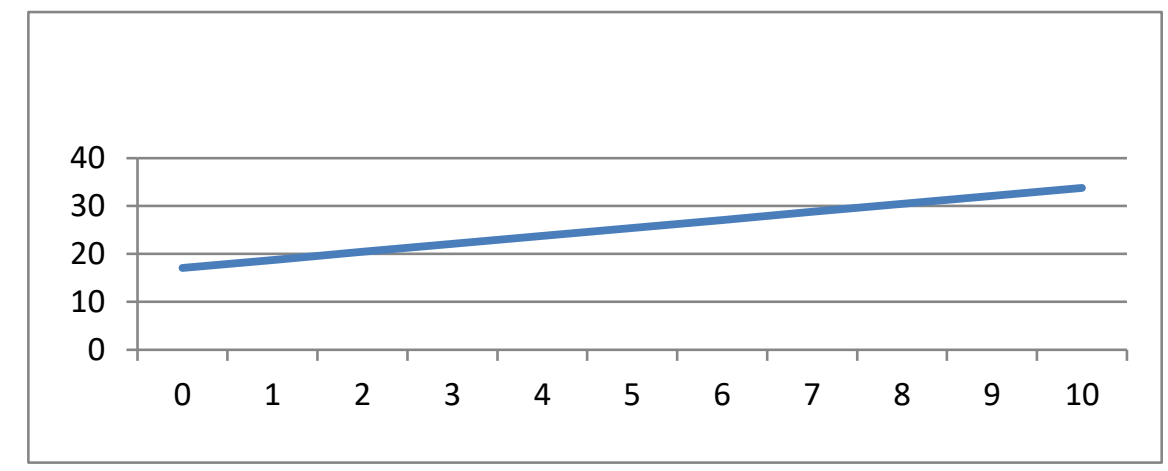

Gambar 3. Grafik Linier Persamaan Regresi

Setelah diketahui adanya hubungan antara prestasi belajar PSG dengan motivasi siswa memasuki dunia kerja, selanjutnya adalah menentukan kriteria hubungan yang dinotasikan dengan koefisien korelasi $\left(r_{x y}\right)$. Untuk menentukan koefisien korelasi tersebut dilakukan perhitungan manual dengan Rumus Product 
Momen dan perhitungan dengan Program SPSS versi 16. Dari hasil perhitungan menggunakan perhitungan manual dan Program SPSS versi 16 (Tabel 4) didapat koefisien korelasi $\left(r_{x y}\right)$ sebesar 0,85. Dengan nilai koefisien korelasi tersebut dapat diinterpretasikan bahwa hubungan prestasi belajar PSG dengan motivasi siswa memasuki dunia kerja tergolong sangat kuat.

Besarnya hubungan prestasi belajar PSG dengan motivasi siswa memasuki dunia kerja oleh koefisien determinasi $\left(r_{x y}{ }^{2}\right)$. Perhitungan koefisien determinasi $\left(r_{x y}{ }^{2}\right)$ :

$$
\begin{aligned}
\mathrm{KD} & =r_{x y}{ }^{2} \times 100 \% \\
& =0,85^{2} \times 100 \% \\
& =0,723 \times 100 \% \\
& =72,3 \%
\end{aligned}
$$

Ini berarti bahwa meningkat atau menurunkan motivasi siswa memasuki dunia kerja $72,30 \%$ dapat dijelaskan oleh besarnya prestasi belajar PSG melalui hubungan linier yang persamaannya adalah $\hat{Y}=$ $17,09+1,67 X$ atau dengan kata lain kontribusi prestasi belajar PSG dengan motivasi siswa memasuki dunia kerja sebesar $72,30 \%$, dan sisanya sebesar $27,70 \%$ ditentukan oleh faktor lain.

Pengujian hipotesis dalam penelitian ini menggunakan Uji $\mathrm{T}$, yaitu untuk mengetahui hubungan yang signifikan antara prestasi belajar PSG dengan motivasi siswa memasuki dunia kerja Bidang Teknik Konstruksi Batu dan Beton. Dari pengujian hipotesis menggunakan Uji T diperoleh $t_{\text {hitung }}>t_{\text {tabel }}$ yaitu 7,22 > 2,09, maka tolak $\mathrm{H}_{0}$, terima $\mathrm{H}_{\mathrm{a}}$. Artinya terdapat hubungan yang signifikan antara prestasi belajar PSG dengan motivasi siswa memasuki dunia kerja.

Berdasarkan analisis dan hasil pengujian hipotesis yang telah dilakukan menunjukkan bahwa hipotesis yang diajukan dalam penelitian ini diterima yaitu terdapat hubungan antara prestasi belajar PSG dengan motivasi siswa memasuki dunia kerja bidang teknik konstruksi batu dan beton. Hal tersebut ditunjukkan dengan nilai $t_{\text {hitung }}$ sebesar 7,22 lebih besar dari pada $t_{\text {tabel }}$ sebesar 2,09 pada taraf kesalahan (alpha) sebesar 0,05.

Pengujian hipotesis ini menggambarkan bahwa prestasi belajar PSG akan mempengaruhi motivasi siswa memasuki dunia kerja. Mahasiswa yang memiliki prestasi belajar PSG akan memiliki motivasi untuk memasuki dunia kerja bidang teknik konstruksi batu dan beton yang didasarkan atas keinginannya sendiri.

Pola hubungan antara variabel prestasi belajar PSG dengan motivasi siswa memasuki dunia kerja ini dinyatakan dengan persamaan regresi $\hat{Y}=17,09+1,67 X$. Persamaan ini memberikan informasi bahwa setiap perubahan baik itu peningkatan maupun penurunan satu satuan prestasi belajar PSG akan diikuti dengan perubahan baik peningkatan maupun penurunan pada motivasi siswa memasuki dunia kerja. Hasil perhitungan pada penelitian ini adalah sebesar 1,67 satuan pada konstanta 17,09.

Hasil analisis korelasi/hubungan antara prestasi belajar PSG dengan motivasi siswa memasuki

Hubungan antara Prestasi Belajar Pendidikan Sistem Ganda dengan Motivasi Siswa Memasuki Dunia Kerja Bidang Teknik Konstruksi Batu dan Beton (Studi Deskriptif Analitis pada Siswa SMK Negeri 4 Jakarta Program Keahlian Teknik 
dunia kerja diperoleh koefisien korelasi $\left(r_{x y}\right)$ sebesar 0,85 . Nilai ini memberikan pengertian bahwa prestasi belajar PSG dengan motivasi siswa memasuki dunia kerja memiliki hubungan yang tergolong sangat kuat. Hal tersebut juga menggambarkan bahwa semakin tinggi prestasi belajar PSG maka semakin tinggi pula motivasi siswa memasuki dunia kerja bidang teknik konstruksi batu dan beton, begitu pula sebaliknya.

Besarnya motivasi siswa memasuki dunia kerja ditentukan oleh variabel prestasi belajar siswa. Besarnya kontribusi prestasi belajar siswa yang berpengaruh terhadap motivasi siswa memasuki dunia kerja dapat diperoleh dengan cara mengkuadratkan koefisien korelasi $\left(r_{x y}\right)$ kemudian dikali $100 \%$. Hasil kuadrat koefisien korelasi tersebut dinamakan koefisien determinasi $\left(r_{x y}{ }^{2}\right)$. Besarnya koefisien determinasi $\left(r_{x y}{ }^{2}\right)$ dalam penelitian ini adalah sebesar $72,30 \%$.

Koefisien determinasi sebesar 72,30\% menggambarkan bahwa prestasi belajar PSG memberikan kontribusi sebesar $72,30 \%$ terhadap motivasi siswa memasuki dunia kerja. Adapun sisa persentase koefisien determinasi sebesar $27,70 \%$ yang berkontribusi pada motivasi siswa memasuki dunia kerja ditentukan oleh faktor.

Dalam penelitian ini terdapat beberapa keterbatasan, yaitu pelaksanaan kegiatan PSG dapat mengganggu pada mata pelajaran kelas normatif, karena pelaksanaan kegiatan PSG menggunakan model sistem blok, sehingga siswa harus terus hadir dalam kegiatan PSG di industri/ lapangan sesuai dengan jadwal yang telah disepakati. Penelitian ini hanya menggunakan sampel di kelas 2 dan hanya salah satu SMK untuk melakukan penelitian ini, akan tetapi hasil uji membuktikan hipotesis diterima bahwa terdapat hubungan yang positif dan signifikan antara prestasi belajar PSG dengan motivasi siswa memasuki dunia kerja bidang teknik konstruksi batu dan beton pada SMK Negeri 4 Jakarta Program Keahlian Teknik Konstruksi Batu Dan Beton.

\section{KESIMPULAN}

Berdasarkan hasil penelitian, maka dapat disimpulkan bahwa hasil penelitian adalah terdapat hubungan yang positif dan signifikan antara prestasi belajar PSG dengan motivasi siswa memasuki dunia kerja bidang teknik konstruksi batu dan beton. Prestasi belajar PSG yang semakin tinggi, maka motivasi siswa untuk memasuki dunia kerja bidang teknik konstruksi batu dan beton semakin tinggi. Karena prestasi belajar PSG dengan motivasi siswa memasuki dunia kerja memiliki hubungan yang sangat tinggi dengan derajat hubungan antara variabel prestasi belajar PSG dengan motivasi siswa memasuki dunia kerja dapat dilihat dari nilai koefisien korelasi $\left(r_{x y}\right)$ sebesar 0,85 . Besarnya kontribusi prestasi belajar PSG terhadap motivasi siswa memasuki dunia kerja ditentukan oleh koefisien determinasi.

Berdasarkan kesimpulan di atas dapat dikemukakan saran-saran, yaitu agar pelaksanaan PSG diusahakan semaksimal mungkin. Dan perlu adanya pendekatan yang berkesinambungan dengan dunia usaha/industri yang nantinya diharapkan dapat merupakan kerjasama yang saling mengisi. Para pendidik dalam hal ini guru, di samping melaksanakan tugas sebagai pendidik hendaknya memperhatikan metode pembelajaran dan media pembelajaran serta memberikan arahan terhadap dunia industri sehingga ketika 
siswa melaksanakan kegiatan PSG dapat termotivasi untuk memasuki dunia kerja. Penelitian ini mengambil sampel yang terbatas pada salah satu SMK di Jakarta, maka penulis sangat mengharapkan adanya penelitian yang sama dan mengambil sampel penelitiannya lebih luas di beberapa SMK.

\section{DAFTAR PUSTAKA}

Amanto, Awal Dias. 2011. Hubungan Bimbingan di Industri terhadap Sikap Kerja Siswa Kelas III Jurusan Teknik Kendaraan Ringan SMK N 1 Seyegan (Skripsi). Yogyakarta : Fakultas Teknik, Universitas Negeri Yogyakarta.

Arikunto, Suharsimi. 2001. Dasar-Dasar Evaluasi Pendidikan. Jakarta : Bumi Aksara.

Azwar, Saifuddin. 1998. Metode Penelitian. Yogyakarta : Pustaka Pelajar.

Hamalik, Oemar. 2003. Perencanaan Pengajaran Berdasarkan Pendekatan Sistem. Jakarta : Bumi Aksara.

Haryanto, Dedi. 2011. Hubungan Antara Kemandirian Belajar terhadap Hasil Belajar Mekanika Teknik II Pada Mahasiswa Program Studi Pendidikan Teknik Bangunan Universitas Negeri Jakarta (Skripsi). Jakarta : Fakultas Teknik, Universitas Negeri Jakarta.

http://belajar.internetsehat.org/pustaka/library-ref.../ilmu-pendidikan.doc. (diakses pada 10 Desember 2011 pukul 01:13).

http://dhimaskasep.files.wordpress.com/2008/03/06-motivasi.pdf. (diakses pada 14 Desember 2011 pukul 11: 57).

http://file.upi.edu/Direktori/fpbs/Jur. Pend. Bahasa Arab/195204141980021-

Dudung Rahmat Hidayat/Hakikat Pendidikan.pdf. (diakses pada 10 Desember 2011 pukul 00: 59).

http://repository.upi.edu/operator/upload/s tb 044617 chapter2.pdf. $\quad$ (diakses pada 10 Desember 2011 pukul 08:55).

http://www.scribd.com/doc/23735462/Pengertian-Prestasi. (diakses pada 10 Desember 2011, pukul 08: 16).

Kadarsah, A. 2004. Hubungan Persepsi tentang Pelaksanaan Pendidikan Sistem Ganda dengan Minat Siswa SMK Negeri 5 Bandung dalam Memasuki Dunia Kerja (Skripsi). Bandung : FPTK UPI Bandung.

Masidjo Ign. 1995. Penilaian Pencapaian Hasil Belajar Siswa di Sekolah. Yogyakarta : Kanisius.

Patriana, Djajang Madya. 1994. Pendidikan Kejuruan di Indonesia. Bandung : Angkasa.

Riduwan. 2004. Belajar Mudah Penelitian untuk Guru-Karyawan dan Peneliti Pemula. Bandung : Alfabeta.

Salam, Burhanuddin. 1997. Pengantar Pedagogik. Jakarta : Rineka Cipta.

Sardiman A.M. 2008. Interaksi dan Motivasi Belajar Mengajar. Jakarta : PT. Raja Grafindo Persada.

Hubungan antara Prestasi Belajar Pendidikan Sistem Ganda dengan Motivasi Siswa Memasuki Dunia Kerja Bidang Teknik Konstruksi Batu dan Beton (Studi Deskriptif Analitis pada Siswa SMK Negeri 4 Jakarta Program Keahlian Teknik 
Sudjana. 2002. Metoda Statistika. Bandung : Tarsito.

Tirtarahardja U, La Sulo. 2000. Pengantar Pendidikan. Jakarta : Erlangga.

Uno, Hamzah B. 2007. Teori Motivasi dan Pengukurannya. Jakarta : Bumi Aksara.

Wahyuningsih, Amalia Sawitri. 2004. Hubungan antara Kecerdasan Emosional dengan Prestasi Belajar pada Siswa Kelas II SMU Lab School Jakarta Timur. Fakultas Psikologi Universitas Persada Indonesia.

Wena, Made. 1996. Pendidikan Sistem Ganda. Bandung : Tarsito.

Winkel WS. 1995. Psikologi Pengajaran. Jakarta : Grasindo.

Yanto, Hendra. 1992. Korelasi antara Motivasi Belajar Intrinsik dengan Prestasi Belajar Siswa Kelas 2 SMK PGRI 1 Bogor Pada Semester 1V Tahun 1990/ 1991. Jakarta : Prodi Psikologi Pendidikan FKIP, IKIP. 